\title{
IMPROVING THE FIFTH GRADE STUDENTS' VOCABULARY ACHIEVEMENT THROUGH SONG INTEGRATED WITH PICTURE
}

\author{
${ }^{1}$ Roudlotun Nurul Laili ${ }^{2}$ Muhammad Nashir \\ 1uutnashir996@gmail.com \\ 1Sekolah Tinggi Ilmu Kesehatan (STIKES) Banyuwangi \\ 2nashirmuhammad123@gmail.com \\ 25ekolah Tinggi Ilmu Kesehatan (STIKES) Banyuwangi
}

\begin{abstract}
Vocabulary as one of language components becomes a vital part in mastering language, especially English as a foreign language. Without having sufficient vocabularies, it is impossible for students to be able to communicate and use language well. Song which is integrated with picture is believed to be able to enlarge the students' vocabulary mastery since both song and picture can attrack students' curiosity and attention. That are beneficial to encourage student'd learning enjoyment. This research was carried out to improve the fifth grade students' vocabulary achievement through song integrated with picture at MI UNGGULAN AL ISHLAH Tembokrejo - Muncar - Banyuwangi. The research design was a classroom action research (CAR) in collaboration with an English teacher which was conducted in two cycles. The data was collected from interview, observation and test. The research result revealed that there was an improvement on the students' vocabulary test and their active involvement during learning process in cycle 1 and 2. The mean score of vocabulary test increased from 69.9 in cycle 1 to 76.38 in cycle 2 and more than $75 \%$ of the students involved actively in the vocabulary teaching learning process in cycle 2 . It met the target criteria of success which means that song which is integrated with picture can enlarge students' vocabulary achievement and make students more enthusiastic in classroom.
\end{abstract}

Key Words: Song, Picture, Vocabulary Achievement.

\begin{abstract}
Abstrak
Kosakata sebagai salah satu komponen penting dalam penguasaan bahasa, terutama bahasa Inggris sebagai bahasa asing. Tanpa memiliki kosakata yang memadai, mustahil bagi siswa untuk dapat berkomunikasi dan menggunakan bahasa dengan baik. Lagu yang terintegrasi dengan gambar diyakini dapat meningkatkan penguasaan kosakata siswa karena lagu dan gambar dapat menarik minat dan perhatian siswa dan mampu mendorong mereka untuk menikmati pembelajaran. Penelitian ini dilakukan untuk meningkatkan prestasi kosakata siswa kelas lima melalui lagu terintegrasi dengan gambar di MI UNGGULAN AL ISHLAH Tembokrejo - Muncar - Banyuwangi. Desain penelitian yang digunakan dalam penelitian ini adalah penelitian tindakan kelas (PTK) berkolaborasi dengan guru bahasa Inggris yang dilakukan dalam dua siklus. Data dikumpulkan dari wawancara, observasi, dan tes. Hasil penelitian menunjukkan bahwa ada peningkatan pada tes kosakata dan partisipasi siswa dalam pembelajaran di kelas pada siklus 1 dan 2. Skor rata-rata tes kosakata siswa meningkat dari 69,9 pada siklus 1 menjadi 76,38 pada siklus 2 dan lebih dari 75\% siswa terlibat aktif dalam proses belajar mengajar kosakata pada siklus 2. Ini memenuhi kriteria
\end{abstract}


target keberhasilan pembelajaran yang menunjukkan bahwa lagu yang terintegrasi dengan gambar dapat meningkatkan penguasaan kosakata siswa dan membuat siswa lebih antusias di kelas.

Kata Kunci: Lagu, Gambar, Penguasaan Kosakata.

\section{INTRODUCTION}

Vocabulary is the main foundation in mastering language. Learning vocabulary is the primary step to learn a foreign language. Good vocabulary mastery will have an impact on good communication process (Nunan, 2006). By having a lot of vocabularies students will easily get what they listen and the reading activity will be fun because they can catch the point about what they have read. Besides by mastering vocabulary students can speak smoothly and compose their idea and concept well. Hatch and Brown (1995:1) define Vocabulary as words list collection used by speakers in language. Vocabulary is all words which contain all the information about the meaning and words usage in the language. Nunan (1998:118) states that the establishment of vocabulary is a crucial aspect in the second language acquisition. Without having compatible vocabularies, students will get many obstacles to communicate with others.

Teaching English to Elementary School students is to teach vocabulary since they learn English for the first time. Teaching vocabulary for young learners like Elementary school students is very challenging because they still have limited concept of conscious, so the language learning must run naturally. Teaching young learners requires extra power to follow the children's characteristics during teaching learning process. So it requires teacher's creativity to present an exciting English learning experience in order to make them feel happy and involved in learning English in which the vocabularies are still unfamiliar for them.

In teaching learning process there are many methods can be used in delivering material but existing methods sometimes cannot guarantee the success of learning, it depends on the teacher's initiative to choose an appropriate method which is suitable with material delivered. Based on the pre test given to the students, the result of English was not satisfying; it was proved by many students got score below minimum criteria of learning / KKM (70) were 24 students or the percentage of the students who got good score category ( $\geq 70$ ) on vocabulary was $42.86 \%$ (18 students). The primary problems faced by students were it was hard for them to memorize vocabulary because English is still new for them and they are still influenced by their mother tongue. The students also had difficulties in understanding the words meaning, pronouncing and spelling the English words because it is relatively different from Indonesian words. In English the way to pronounce and the way to write the words is different.

Based on the informal interview with the English teacher of MI UNGGULAN AL ISLAH Tembokrejo - Muncar, she commonly teaches the students by using textbook. 
She is more stressful in teaching vocabulary because vocabulary is the central of language teaching and learning. This means that by mastering vocabulary the studentss might produce so many sentences easily either in spoken or written. Without adequate vocabularies it is impossible for students to be able to use language. The English teacher usually taught the students by vocabulary repetition or drilling and translated the meaning in Indonesia then continued by giving students' activity and tasks available in textbook. Besides the limited time and media of teaching also became problems for teacher.

Based on the problems above the researchers offered song which is integrated with picture to make learning variation and create fun atmosphere in order that students do not experience boredom since young learners are happy engaged in singing a song. Paquette (2008: 2) affirms that many languages skills like grammar, vocabulary, and pronunciation can be taught by using songs and some body movements can be supplemented to create meaningful learning. It is in line with Mejzini (2016) who states that to construct an exciting and amusing atmosphere in the classroom especially in teaching and learning foreign language, the use of song can be very useful since it can stimulate students and bring up enjoyment and pleasurable situation in class. The rhythms and lyrics in song can facilitate the students in memorizing the words and there are many evidences proved it (Wrenshall, 2002: 43).

The studies about the use of song and pictures for language teaching are abounding. Gushendra (2017) performed an experimental study and the result showed that the students who were taught by using song have good progress on their vocabulary mastery. While Donal's (2012) study proved that pictures can upgrade the vocabularies of students at Pasir Pangaraian University in Agribusiness study program. The students' mean score increased from 53 to 63. In addition, pictures can amplify students' enthusiasm and attention in learning English.

Besides, the comparative study did by Akbarpour and Roohani (2015) and the finding told that there was no significant difference between both song method and non-song method on the students' English vocabulary advancement. Based on the previous studies above, the researchers are interested to reexamine the use of song which is integrated with picture to enhance the students' vocabulary development. Picture can translate the abstract concept into more realistic thing, so students do not only imagine what the meaning of thing is on the word they say. In this case researchers used song integrated with picture because by using song the students will be easier memorizing the vocabularies presented in song lyrics. While by using picture will bring students in real life situation learning process, so the combination both songs and pictures can arise the students' positive mood and enhance their vocabulary achievement.

\section{The Implementation of Teaching Vocabulary by Using Song Integrated with Picture}

Some steps in teaching vocabulary through English song integrated with picture are determining the vocabulary material being taught based on the curriculum, making song lyric or song can be taken the existing song available in which it is 
related to the material being taught, drawing, printing or taking the pictures of some vocabularies stated in song lyric. It continued by teaching the words or idioms of the songs, asking the students to imitate the pronunciation read by the teacher. Then the teacher sings the whole song for all students. In this case, the students listen to the teacher. After that students repeat the words line by line while the teacher makes beats by knocking the table to introduce the rhythm of song to the students. Sing the words with the appropriate tone line by line and ask the students to follow the teacher. Do in several times till the whole students can sing the song well with good pronunciation. And the last the teachers asks the students to sing the song without imitating the teacher simultaneously. While students sing a song, the teacher shows the picture. The pictures shown must be appropriate with what students said in a song lyric.

\section{RESEARCH METHODS}

This research was a classroom action research (CAR) with cycle model that was intended to enhance the vocabulary achievement of the fifth grade students of elementary school. Lodico, Spaulding and Voegtle (2010:313) state that an action research is a type of research proposed to impose immediate changes in classroom, to recover the recent class condition, and raise the quality of educational setting. It is potential to produce changes quickly in the classroom condition because the research is carried out by educators in their own work settings. The research subjects were the fifth grade students of MI UNGGULAN AL ISLAH Tembokrejo - Muncar - Banyuwangi in the 2018/2019 academic year with the number of the respondents was 42 students. This research was done collaboratively with an English teacher.

This action research was conducted in two cycles in which each cycle consists of four stages: planning, implementing planning, observing the implementation, and reflecting the process and the implementation result (Latief, 2013: 143). Here are the procedures in administering an action research:

a. Planning

The following were the activities done to plan the action such as choosing the themes of material based on curriculum, constructing the lesson plans collaboratively with the English teacher, preparing the material by making song lyrics or selecting song from sources available, preparing pictures to be shown to the students while singing a song, preparing the students' worksheets and observation guide in checklist, constructing the vocabulary test, and determining the success criteria of the action.

b. Implementing the plan

This research was conducted during the school hours according to the schedule of the class. The English teacher carried out the action and the researchers as collaborator observed and made notes about everything that happen during the teaching learning process.

c. Observing the implementation 
The observation was done to get the data on how far the use of song integrated with picture can improve students' vocabulary achievement and their active participation in class. The data was taken from vocabulary test and observation checklist. The criteria used to evaluate the success of the actions were:

1. There are $75 \%$ of the students got score $\geq 70$ in vocabulary test and the mean score of vocabulary test was at least 70 .

2. There are $75 \%$ of the students involved actively in the vocabulary teaching learning process.

While the checklist contained some indicators being observed, they were: 1 ) the students paid attention to the teacher's explanation/listened the teacher when explained words in song lyric, 2) the students repeated after the teacher/followed singing a song, 3) the students looked at the pictures shown by the teacher while singing a song, and 4) the students mentioned the words or the things on the pictures shown by the teacher. The students were classified as active if they did at least three of four observation indicators stated in the checklist.

d. Reflecting

Reflect the results of the actions. All the data taken were analyzed to know how much the implemented method has effectively solved the students' problem in their learning. It was intended to know the weaknesses and the strengths of the actions. If the success criteria were achieved, then the research was stopped. But if it did not meet the criteria of success, researchers continued to the next cycle by revising some necessary aspects, especially the teaching technique.

\section{FINDING AND DISCUSSION}

\section{The Result of Vocabulary Achievement Test}

In this study, researchers compared the students' vocabulary score in preliminary study by conducting pretest and the result of post test given after doing the action in cycle 1 and 2. Each cycle consisted of two meetings and giving post test after the action. The research has achieved the goal if $75 \%$ students got score equal or more than 70 and the mean score of vocabulary test in the classroom was at least 70.

Table 1. The Mean Score Result of Pre test and Post Test

\begin{tabular}{|c|c|c|}
\hline Test & Mean Score & $\begin{array}{c}\text { Percentage of Students who got } \\
\mathbf{2 7 0}\end{array}$ \\
\hline Pre Test & 59.64 & $42.86 \%$ \\
\hline Post Test Cycle 1 & 69.9 & $69.05 \%$ \\
\hline Post Test Cycle 2 & 76.38 & $83.33 \%$ \\
\hline
\end{tabular}

Based on the table 1 in pre test there was 18 students (59.64\%) who got score equal or more than 70. It illustrated that students' vocabulary achievement was poor and it was necessary to be raised. In cycle 1 the students' result of vocabulary has increased. The number of students who got $\geq 70$ was 29 students $(69.9 \%)$ and the students' mean score was 69.9. The actions given in the first cycle had not been 
successful yet because it was below the percentage required in this research that was at least $75 \%$ of the students got scores at least 70 and the mean score of vocabulary test in the classroom was at least 70 . So, it was necessary to conduct the second cycle by revising some teaching techniques dealing with selection of song instrument, which was by choosing faster and energetic instrument while adding and doing body movement in order to obtain students' keen and spirit. Then choose and select clearer and more exciting pictures to make students easier catch the point stated in the picture.

The students' vocabulary score in cycle 2 showed the enhancement, the students who got score $\geq 70$ was $83.33 \%$ (35 students). The mean score of vocabulary test was 76.38, it was categorized as good. It had achieved the requirement in this classroom action research, the target evaluation criteria had reached. The conclusion is the implementation of song integrated with picture was successful to improve the students' vocabulary achievement. Thus, the action was stopped.

\section{The Result of Students' Active Participation during Teaching Learning Process}

The observation was done to know the students' active involvement in vocabulary teaching learning process by using song which was integrated with picture. It was done in each meeting of each cycle. Here is the result of students' active involvement in the classroom.

Table 2. The Observation Result on Students' Active Involvement

\begin{tabular}{|c|c|c|}
\hline Meeting & $\begin{array}{c}\text { The Total of Active } \\
\text { Students }\end{array}$ & $\begin{array}{c}\text { The percentage of Active } \\
\text { Students }\end{array}$ \\
\hline Cycle 1 Meeting 1 & 27 & $64.29 \%$ \\
\hline Cycle 1 Meeting 2 & 24 & $57.14 \%$ \\
\hline Cycle 2 Meeting 1 & 32 & $76.19 \%$ \\
\hline Cycle 2 Meeting 2 & 34 & $80.95 \%$ \\
\hline
\end{tabular}

The result of observation on table 2 , in cycle 1 meeting 1 showed 27 students (64.29\%) were actively involved in classroom, while in cycle 1 meeting 2 the students' participation was decreased. There were only 24 students $(57.14 \%)$ who participated actively in learning process due to they looked less interested because the song is too slow and it was kind of difficult for them to say and pronounce vocabularies taught in song. Those percentages did not complete the criteria of success yet. So it continued to the cycle 2 . In cycle 2 meeting 1 the percentage of students' participation was $76.19 \%$ (32 students), while in cycle 2 meeting 1 the percentage of students' involvement in teaching learning process was increased. There were 34 students $(80.95 \%)$ involved the learning process actively. It means that the target evaluation criteria had been reached because more than $75 \%$ of the students participated actively in the vocabulary teaching learning process by using song integrated with picture in each meeting. The actions done in this cycle had been successful therefore, the actions were stopped. 


\section{CONCLUSION}

The use of song which is integrated with picture could improve students' vocabulary mastery at the fifth grade of MI UNGGULAN Al ISHLAH Tembokrejo Muncar - Banyuwangi in 2018/2019 academic year since song could stimulate students and make them easier remembering the words in repetition when singing song. Then by integrating it with picture, it make students easily memorized the meaning of words they sang while seeing picture shown by the teacher. Besides, using song incorporate with picture in teaching are make learning more attractive and fun for children, help students focus and comprehend the material, make students more relax and get good mood, motivate them to involve actively in the classroom, activate students' sensory, and stimulate students' concentration and awareness.The enhancement could be seen from the mean score of students' vocabulary test in cycle 1 was 69.9 improved to 76.38 in cycle 2 . The number of students who got good score $\geq 70$ was 29 students $(69.9 \%)$ in cycle 1 , and in cycle 2 there were 35 students $(83.33 \%)$ who got score $\geq 70$. Therefore, the criterion required in this research which was $75 \%$ of students got scores at least 70 was fulfilled.

In addition, the students' participation in classroom during teaching learning process by using song integrated with picture also raised. It was shown by the percentage of students who joined in learning in cycle 1 meeting 1 as many as 27 students (64.29\%) and in cycle 1 meeting 2 there were 24 students were actively involved in classroom. The improvement was in cycle 2 meeting 1 there were 32 students $(76.19 \%)$ who participated actively in class and in cycle 2 meeting 2 there the percentage of students' active participation was $80.95 \%$ (34 students). In cycle 2 all the criterion required in this research was reached the target criteria. It showed clearly that song which is integrated with picture was effective for teaching vocabulary at young learners.

\section{REFERENCES}

Akbarpour, S. \& Roohani, A. 2015. The Comparative Impact of Song and Nonsong Vocabulary Instructions. International Journal of Language Learning and Applied Linguistics World 10 (2), 1-12.

Donal, A. 2012. Improving the Esp Students' Vocabulary by Using Pictures in Agribusiness Study Program of The University of Pasir Pengaraian. EDU RESEARCH; Jurnal Pendidikan 1 (1), 77-95.

Hatch, E. \& Brown, C. 1995. Vocabulary, Semantic, and Language Education. New York : Cambridge University Press.

Latief, M.A. 2013. Research Methods on Language Learning: An Introduction. Malang: UM Press. 
Lodico, M. G., Spaulding, T. D., \& Voegtle, K. H. 2010. Methods in Educational Research. San Fransisco: Jossey Bass.

Mejzini, M. 2016. Teaching Children through Songs, Chants and Rhymes. European Journal of English Language Teaching1(2),104-113.

Nunan, D. 1998. Designing Tasks for the Communicative Classroom. New York : Cambridge University Press.

Nunan, D. 2006. Practical English Language Teaching: Young Learners. New York: McGrawhill Companies, Inc.

Paquette, K. 2008. Using Music to Support the Literacy Development of Young English Language Learners. Available at http://www.Proquest.Com/book. Com/book/the-literacy-development-of-young-english-language-learners.

Rilley, V., Ward, S., Malley, A. 1999. Very Young Learners. New York : Cambridge University Press

Wrenshall, J. 2002. Using Song to Improve Communication Competence. Bangkok : AUA Language Center. 